\title{
Altman's Z"-Scores for financial distress predictions among food and beverages industry in Indonesia
}

\author{
Ruth Samantha Hamzah ${ }^{1 *}$, Mutiara Lusiana Annisa ${ }^{2}$ \\ Universitas Sriwijaya, Politeknik Palcomtech \\ ruth_samantha@fe.unsri.ac.id, mutiara_annisa@palcomtech.ac.id
}

*Corresponding Author

Diajukan : 15 Januari 2022

Disetujui : 4 Februari 2022

Dipublikasi : 7 Februari 2022

\begin{abstract}
The food and beverage industry is an accelerated sector in Indonesia. They are predicted to be one of the pivotal sectors supporting manufacturing and economic growth. This study aims to predict financial distress on food and beverage industries in Indonesia using Altman's Z"-Score modification model. The samples of this study are 48 firm-year observations in the period of 2018 and 2019. The results show there are 2.1 percent of firms experienced financial distress $(Z<1.10)$, 2.1 percent of firms was in grey area, i.e., prone to financial distress $(Z<1.10<2.60)$, and 95.8 percent of firms did not experience financial distress. It implies that food and beverage industries in Indonesia is relatively safe if there is no economic shock. Furthermore, the prediction is able to be considered either for stakeholders or shareholders in decision making and financial policies, respectively. Nevertheless, the signal is given for firms that are included in financial distress and grey area.
\end{abstract}

Keywords: Altman's Z-Score; Financial Distress; Bankruptcy; Food and beverage industry

\section{PENDAHULUAN}

Korporasi di seluruh dunia telah mengalami dampak yang besar sebagai akibat dari pandemi Covid-19. Situasi ini dapat menyebabkan bisnis mengalami kebangkrutan karena penurunan penjualan yang diikuti dengan penurunan pendapatan. Jika kegiatan operasi perusahaan berhenti, tidak ada kas yang harus dikelola. Penurunan penjualan telah memicu kesulitan keuangan perusahaan, kondisi ini disebut dengan financial distress. Kesulitan keuangan menyebabkan ketidakstabilan dalam pengelolaan keuangan dan merupakan sinyal kebangkrutan. Untuk mencegah hal tersebut, perusahaan harus merencanakan strategi dalam mengelola keuangannya melalui kegiatan operasi.

Dalam bisnis, perusahaan dibagi menjadi dua kategori, yaitu perusahaan privat dan perusahaan publik. Perusahaan publik atau yang disebut go public adalah perusahaan yang menerbitkan saham yang ditawarkan kepada investor, sementara perusahaan privat mengelola modal internal. Di Indonesia, perusahaan publik menawarkan sahamnya di Bursa Efek Indonesia (BEI). BEI merupakan tempat yang memperdagangkan jual beli efek termasuk saham di pasar modal. Perusahaan yang go public harus diikutsertakan di pasar modal tersebut. Bagi pihak eksternal, informasi tentang kondisi keuangan suatu perusahaan sangat penting untuk melakukan keputusan investasi. Sedangkan, untuk pihak lain seperti kreditur dan pemerintah menggunakan informasi ini untuk penilaian kinerja perusahaan.

Financial distress memberikan dampak yang sangat besar bagi semua pihak yang terkait sehingga perusahaan yang mengalami kondisi ini harus lebih berhati-hati dalam memeriksa kondisi keuangannya. Berdasarkan literatur, ada beberapa metode yang digunakan untuk mengukur financial distress. Namun, penelitian sebelumnya menyarankan model Altman's Z-Score sebagai salah satu metode yang akurat di antara model lainnya (lihat tabel 1) (Hamid, Akter \& Rab, 2016; Altman, et al, 2016; Patunrui \& Yati, 2017; Panigrahi, 2019).

Penelitian ini menggunakan perusahaan manufaktur yang bergerak di bidang makanan dan 
minuman sebagai objek penelitian dan memilih tahun 2018 dan 2019 sebagai periode penelitian. Tahun 2020 dikeluarkan dari masa observasi karena adanya wabah pandemi Covid-19. Seperti yang disebutkan sebelumnya, bahwa pandemi memberikan dampak yang sangat besar bagi semua sektor korporasi termasuk sektor makanan dan minuman. Hal ini juga mempengaruhi data keuangan, sehingga sebaran data akan terlalu luas dan menyebabkan banyaknya outlier dari sampel penelitian.

Industri makanan dan minuman diproyeksikan menjadi salah satu sektor dominan yang menopang pertumbuhan manufaktur dan ekonomi di tahun-tahun mendatang. Peran penting sektor strategis ini terlihat dari kontribusinya yang konsisten dan signifikan terhadap produk domestik bruto (PDB) industri nonmigas serta realisasi investasi yang terus meningkat. Untuk itu, pemerintah terus berupaya menjaga ketersediaan bahan baku yang dibutuhkan industri makanan dan minuman agar lebih produktif dan berdaya saing global. Kinerja industri makanan dan minuman selama periode 2015-2019 tumbuh rata-rata 8,16\% atau di atas rata-rata pertumbuhan industri pengolahan nonmigas sebesar 4,69\%. Di tengah dampak pandemi, sepanjang triwulan IV tahun 2020 terjadi kontraksi pertumbuhan industri nonmigas sebesar 2,52\%. Namun demikian, industri makanan dan minuman masih mampu tumbuh positif sebesar $1,58 \%$ pada tahun 2020 (Kementerian Perindustrian, 2021).

Namun demikian, industri makanan dan minuman rentan terhadap financial distress dan sensitif terhadap perubahan seperti perubahan harga bahan baku dan kondisi eksternal seperti inflasi dan krisis. Oleh karena itu, dengan melakukan penilaian secara berkala, perusahaan makanan dan minuman dapat melihat kemungkinan financial distress yang berujung pada kebangkrutan. Selanjutnya, perusahaan yang terlibat dalam kesulitan keuangan harus meninjau operasi mereka untuk mengatur kembali kebijakan tertentu sesuai dengan kondisi keuangan. Dengan demikian keberlangsungan perusahaan tetap terjaga dengan tetap memperhatikan sinyal dari kondisi financial distress.

\section{Teori Sinyal}

\section{STUDI LITERATUR}

Teori sinyal menyatakan bahwa dengan memberikan informasi, pemilik informasi berusaha memberikan informasi yang dapat digunakan oleh penerima informasi (Morris, 1987). Selain itu, teori sinyal menjelaskan bahwa manajemen bertindak sebagai agen, memiliki dorongan untuk memberikan informasi laporan keuangan kepada pihak eksternal. Dari laporan keuangan dapat diketahui apakah perusahaan dalam kondisi stabil atau mengalami kesulitan keuangan. Memperoleh keuntungan dalam jangka waktu yang panjang masing-masing, merupakan ciri dari kinerja keuangan yang stabil. Perusahaan yang tidak mengalami financial distress menunjukkan kondisi keuangan yang lebih baik dibandingkan dengan perusahaan yang pernah mengalami financial distress. Selain itu, kemungkinan kebangkrutan dapat muncul pada perusahaan yang mengalami financial distress. Dengan sinyal tersebut, pihak internal dapat mengevaluasi kinerja keuangannya dengan mempertimbangkan rasio-rasio keuangan, serta menjadi pertimbangan pihak eksternal mengenai keputusan investasinya.

\section{Financial Distress}

Financial distress dipandang mahal karena menciptakan kecenderungan bagi perusahaan untuk melakukan hal-hal yang mengancam bagi pemegang utang dan pemangku kepentingan nonkeuangan yang mengganggu akses kredit dan meningkatkan biaya atas hubungan pemangku kepentingan (Opler \& Titman, 1994). Financial distress sebagai tahapan penurunan kondisi keuangan yang terjadi sebelum terjadinya kebangkrutan atau likuidasi. Kesulitan keuangan dimulai dari ketidakmampuan untuk memenuhi kewajibannya, terutama kewajiban jangka pendek termasuk kewajiban likuiditas, serta kewajiban dalam kategori solvabilitas. Menurut Altman (1968) financial distress adalah konsep luas yang terdiri dari beberapa situasi dimana perusahaan menghadapi kesulitan keuangan. Istilah umum untuk menggambarkan situasi tersebut adalah kegagalan, insolvensi, default, dan kebangkrutan. Jika perusahaan mengetahui bahwa kondisi keuangannya lemah, dapat membuat pemegang saham seperti kreditur kehilangan kepercayaannya. Kondisi tersebut memicu pemegang saham untuk keluar dari perusahaan tersebut. Jika perusahaan gagal untuk memecahkan kondisi keuangan, maka itu adalah peringatan bahwa kesulitan keuangan 
menyebabkan kebangkrutan. Ada beberapa penelitian sebelumnya yang melakukan model Altman's Z-Score untuk memprediksi financial distress (lihat Tabel 1).

Tabel 1. Penelitian Terdahulu yang Menggunakan Model Altman's Z-Score

\begin{tabular}{|c|c|c|c|}
\hline Penulis & Pengukuran & Fokus Penelitian & Hasil Penelitian \\
\hline $\begin{array}{l}\text { Altman, E. I., Iwanicz- } \\
\text { Drozdowska, M., Laitinen, } \\
\text { E. K., \& Suvas, A. (2016) }\end{array}$ & $\begin{array}{lr}\begin{array}{l}\text { Original } \\
\text { Score }\end{array} & Z \text { model } \\
\text { oleh } & \text { Altman } \\
(1983) & \end{array}$ & $\begin{array}{l}31 \text { negara Eropa dan } \\
\text { tiga negara non- } \\
\text { Eropa untuk } \\
\text { perusahaan } \\
\text { manufaktur dan non- } \\
\text { manufaktur privat } \\
\text { dan publik. }\end{array}$ & $\begin{array}{l}\text { Model Z"-Score asli } \\
\text { memungkinkan } \\
\text { untuk mengekstrak } \\
\text { model negara yang } \\
\text { lebih efisien untuk } \\
\text { sebagian besar } \\
\text { negara Eropa dan } \\
\text { untuk negara-negara } \\
\text { non-Eropa } \\
\text { menggunakan empat } \\
\text { variabel asli disertai } \\
\text { dengan satu set } \\
\text { variabel tambahan. }\end{array}$ \\
\hline $\begin{array}{l}\text { Katarina Intan Afni } \\
\text { Patunrui and Sri Yati } \\
\text { (2017) }\end{array}$ & $\begin{array}{l}\text { Altman's Z- } \\
\text { Score model }\end{array}$ & $\begin{array}{l}\text { Perusahaan Farmasi } \\
\text { yang terdaftar di BEI }\end{array}$ & $\begin{array}{l}\text { Model Altman Z- } \\
\text { Score dapat } \\
\text { diimplementasikan } \\
\text { dalam mendeteksi } \\
\text { kemungkinan } \\
\text { financial distress di } \\
\text { perusahaan farmasi. }\end{array}$ \\
\hline Ashok Panigrahi (2019) & $\begin{array}{ll}\text { Altman's } & \text { 'Z' } \\
\text { Score Model } & \end{array}$ & $\begin{array}{l}\text { Beberapa perusahaan } \\
\text { farmasi yang terpilih }\end{array}$ & $\begin{array}{l}\text { Industri farmasi } \\
\text { memiliki posisi } \\
\text { keuangan yang sehat } \\
\text { karena Z-Score jauh } \\
\text { di atas nilai batas. }\end{array}$ \\
\hline $\begin{array}{l}\text { Tania Hamid, Farzana } \\
\text { Akter \& Naharin Binte Rab } \\
\text { (2016) }\end{array}$ & $\begin{array}{lr}\text { Altman's } & Z- \\
\text { Score } & \text { Model } \\
(1965) & \end{array}$ & $\begin{array}{l}15 \text { LKNB } \\
\text { Bangladesh yang } \\
\text { diperdagangkan } \\
\text { secara publik selama } \\
\text { lima tahun mulai dari } \\
2011 \text { hingga } 2015\end{array}$ & $\begin{array}{l}\text { Hasilnya } \\
\text { menunjukkan bahwa } \\
\text { sebagian besar } \\
\text { sampel LKNB } \\
\text { berada di zona } \\
\text { 'Distress', beberapa } \\
\text { sampel diakui secara } \\
\text { nasional dan } \\
\text { internasional atas } \\
\text { kinerja dan } \\
\text { kontribusinya yang } \\
\text { luar biasa terhadap } \\
\text { perkembangan } \\
\text { industri dan ekonomi } \\
\text { negara, tetapi gagal } \\
\text { mencapai nilai } \\
\text { minimum. Sebagian } \\
\text { besar perusahaan } \\
\text { berada pada tingkat } \\
\text { kebangkrutan. }\end{array}$ \\
\hline
\end{tabular}

Dalam memeriksa kondisi keuangan, perlu dilakukan penilaian terhadap laporan keuangan. Selanjutnya, rasio keuangan adalah salah satu teknik yang digunakan dalam memprediksi kesulitan keuangan. Disini kami menggunakan model Altman's Z"-Score yang merupakan modifikasi dari model sebelumnya yang juga dikembangkan oleh Altman dalam memprediksi financial distress. 
Model ini ditujukan untuk data berbasis akuntansi yang tersedia secara publik dalam bentuk laporan keuangan.

\section{Industri Makanan dan Minuman di Indonesia}

Industri makanan dan minuman saat ini menghadapi tantangan sekaligus tekanan di tengah globalisasi perdagangan bebas. Penerapan perdagangan bebas dengan berbagai negara memberikan tantangan banyaknya pesaing dan berbagai faktor lainnya memungkinkan kondisi buruk terjadi jika tidak ada strategi pasti untuk mengatasi kondisi tersebut (Nurhayati, Dewi, \& Fajri, 2020). Salah satu kemungkinan terburuk adalah perusahaan kalah dalam persaingan yang dapat mengakibatkan kebangkrutan. Financial distress merupakan tanda kebangkrutan sehingga penting untuk memeriksa kondisi keuangan perusahaan secara berkala. Namun demikian, industri makanan dan minuman merupakan industri yang menawarkan kebutuhan dan kebutuhan sehari-hari kepada masyarakat maupun industri lainnya. Perusahaan makanan dan minuman harus kreatif dan inovatif bagaimana mereka bertahan dalam operasi.

Di Indonesia, perusahaan makanan dan minuman semakin banyak jumlahnya karena makanan dan minuman merupakan salah satu kebutuhan primer manusia selain sandang dan papan, oleh karena itu industri makanan dan minuman merupakan bisnis yang prospektif. Hal ini juga didukung dengan perkembangan perekonomian Indonesia yang semakin meningkat dari tahun ke tahun. Perusahaan makanan dan minuman umumnya melakukan go public untuk mendapatkan tambahan modal. Hal ini terbukti pada saat krisis global yang terjadi sekitar tahun 2008, satu-satunya industri yang bertahan adalah makanan dan minuman.

Dari sisi investasi, industri makanan dan minuman lebih diminati oleh investor domestik selama periode 2007-2011. Selanjutnya, industri ini diproyeksikan menjadi salah satu sektor andalan untuk mendukung pertumbuhan manufaktur dan perekonomian nasional. Peran penting sektor strategis ini terlihat dari kontribusinya yang konsisten dan signifikan terhadap produk domestik bruto (PDB) industri nonmigas serta realisasi investasi yang terus meningkat. Oleh karena itu, peluang untuk berinvestasi di sektor makanan dan minuman cukup menjanjikan. Sehingga menjadikan industri ini sebagai salah satu sektor penting di Indonesia.

\section{Kerangka Pemikiran}

Penelitian ini bertujuan untuk memprediksi financial distress pada perusahaan publik di industri makanan dan minuman. Untuk mencapai tujuan ini, kami menggunakan model Altman's Z"-Score yang diyakini sebagai model paling akurat dalam prediksi financial distress secara umum. Dengan tersedianya data prediksi financial distress dapat digunakan untuk menjembatani kelangkaan informasi tersebut dari pemangku kepentingan kepada pemegang saham maupun pembuat kebijakan. Kerangka teori penelitian ini digambarkan pada gambar 1.

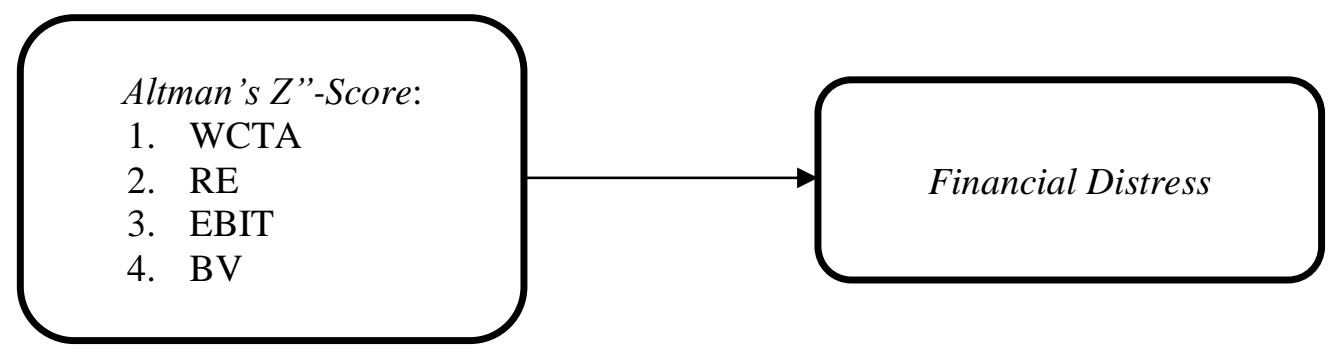

Gambar 1. Kerangka Pemikiran

\section{Sampel}

\section{METHOD}

Sampel dalam penelitian ini adalah perusahaan makanan dan minuman yang terdaftar di BEI pada periode 2018 dan 2019. Sampel yang dipilih sebanyak 24 sampel dengan metode purposive sampling, sehingga diperoleh 48 data panel sekunder observasi tahun perusahaan. Kami mengumpulkan data dari laporan tahunan dan laporan keuangan yang tersedia di situs resmi Bursa Efek Indonesia. Daftar sampel disajikan pada tabel 2. 
Owner: Riset \& Jurnal Akuntansi

e-ISSN : 2548-9224|p-ISSN : 2548-7507

Volume 6 Nomor 1, Januari 2022

DOI : https://doi.org/10.33395/owner.v6i1.696

Tabel 2. Daftar Sampel

\begin{tabular}{lc}
\hline \multicolumn{1}{c}{ Perusahaan } & Kode \\
\hline Akasha Wira International Tbk & ADES \\
Tiga Pilar Sejahtera Food Tbk & AISA \\
Tri Banyan Tirta Tbk & ALTO \\
Bumi Teknokultura Unggul Tbk & BTEK \\
Budi Starch \& Sweetener Tbk & BUDI \\
Campina Ice Cream Industry Tbk & CAMP \\
Wilmar Cahaya Indonesia Tbk & CEKA \\
Sariguna Primatirta Tbk & CLEO \\
Delta Djakrta Tbk & DLTA \\
Buyung Poetra Sembada Tbk & HOKI \\
Indofood CBP Sukses Makmur Tbk & ICPB \\
Inti Agri Resources Tbk & IIKP \\
Indofood Sukses Makmur Tbk & INDF \\
Magna Investama Mandiri Tbk & MGNA \\
Multi Bintang Indonesia Tbk & MLBI \\
Mayora IndahTbk & MYOR \\
Pratama Abadi Nusa Industri Tbk & PANI \\
Prima Cakrawala Abadi Tbk & PCAR \\
Prasidha Aneka Niaga Tbk & PSDN \\
Nippon Indosari Corpindo Tbk & ROTI \\
Sekar Bumi Tbk & SKBM \\
Sekar Laut Tbk & SKLT \\
Siantar Top Tbk & STTP \\
Ultra Jaya Milk Industry \& Trading Company & ULTJ \\
Tbk & \\
\hline Suma Bura Efek Indonesia (2020)
\end{tabular}

Sumber: Bursa Efek Indonesia (2020)

\section{Operasional Variabel}

Penelitian ini terdiri dari variabel-variabel yang digunakan pada model Altman's Z"-Score. Penjelasan masing-masing variabel serta pengukurannya disajikan pada tabel 3.

Tabel 3. Operasional Variabel

\begin{tabular}{|c|c|c|c|}
\hline Variabel & Operasional Variabel & Skala & Pengukuran \\
\hline \multicolumn{4}{|c|}{ Variabel Dependen } \\
\hline $\begin{array}{l}\text { Overall All } \\
\text { atau Z”-Score } \\
\text { (Y) }\end{array}$ & $\begin{array}{l}\text { Penurunan kondisi keuangan } \\
\text { (financial distress) }\end{array}$ & Rasio & $Z=3,25+6,56 X_{1}+3,26 X_{2}+6,72 X_{3}+1,05 X_{4}$ \\
\hline \multicolumn{4}{|c|}{ Variabel Independen } \\
\hline $\begin{array}{l}\text { Working } \\
\text { Capital to } \\
\text { Total Asset } \\
\left(\mathrm{X}_{1}\right)\end{array}$ & $\begin{array}{l}\text { Rasio untuk mengukur jumlah } \\
\text { modal kerja bersih dalam suatu } \\
\text { perusahaan dibandingkan } \\
\text { dengan total asetnya }\end{array}$ & Rasio & WCTA $=\frac{\text { Working Capital }}{\text { Total Asset }} \times 100 \%$ \\
\hline $\begin{array}{l}\text { Returned } \\
\text { Earning to } \\
\text { Total Asset } \\
\text { Ratio }\left(\mathrm{X}_{2}\right)\end{array}$ & $\begin{array}{l}\text { Rasio untuk mengukur jumlah } \\
\text { laba ditahan dibandingkan } \\
\text { dengan aset keseluruhan } \\
\text { perusahaan }\end{array}$ & Rasio & $\mathrm{RE}=\frac{\text { Return Earnings }}{\text { Total Asset }} \times 100 \%$ \\
\hline $\begin{array}{l}\text { Earnings } \\
\text { Before Interest } \\
\text { and Taxes to }\end{array}$ & $\begin{array}{l}\text { Rasio untuk mengukur laba } \\
\text { sebelum bunga dan pajak } \\
\text { dibandingkan dengan total aset } \\
\text { perusahaan }\end{array}$ & Rasio & $\mathrm{EBIT}=\frac{\text { Earnings Before Tax and Interest }}{\text { Total Asset }} \times 100 \%$ \\
\hline
\end{tabular}


Owner: Riset \& Jurnal Akuntansi

e-ISSN : 2548-9224 |p-ISSN : 2548-7507

Volume 6 Nomor 1, Januari 2022

DOI : https://doi.org/10.33395/owner.v6i1.696

\begin{tabular}{|l|l|l|l|}
\hline $\begin{array}{l}\text { Total Assets } \\
\text { Ratio }\left(\mathrm{X}_{3}\right)\end{array}$ & & \\
\hline Book Value of & Rasio untuk mengukur nilai & Rasio & $\mathrm{BV}=\frac{\text { Book Value of Equity }}{\text { Total Debt }} \times 100 \%$ \\
Equity to Book & buku ekuitas suatu perusahaan & & \\
Value of Total & dibandingkan dengan nilai & & \\
Debt Ratio & bukunya dari total hutang & & \\
$\left(\mathrm{X}_{4}\right)$ & & \\
\hline
\end{tabular}

\section{Teknik Analisis Data}

Terdapat lima teknik yang paling populer dalam memprediksi financial distress, (1) analisis diskriminan ganda, (2) model logit, (3) jaringan saraf, (4) klaim kontingen, dan (5) analisis univariat (Altman, et al., 2016). Pada mulanya, Altman (1968) telah melakukan penelitian pendahuluan dalam memprediksi financial distress dengan mengembangkan model Altman's Z-Score di akhir 1960-an. Setelah karyanya yang fenomenal, banyak lagi metode yang dikembangkan dengan menggunakan pendekatan yang hampir sama (Agarwal \& Taffler, 2008; Das, et al., 2009; Bauer \& Agarwal, 2014). Meskipun ditujukan untuk tujuan tertentu, namun model Altman's Z-Score terdahulu saat ini terus digunakan di seluruh dunia sebagai alat utama atau pendukung untuk prediksi dan analisis kebangkrutan atau kesulitan keuangan baik dalam penelitian maupun dalam praktik. Oleh karena itu, Z-Score akurat untuk keperluan umum, terutama dalam jangka waktu yang pendek (Altman, et al, 2016).

Namun, dalam penelitian ini kami menggunakan model modifikasi Z-Score yaitu model Z"Score. Dalam model Z-Score yang dimodifikasi, Altman menghilangkan penjualan terhadap total aset dan mengganti jumlah nilai koefisien dari semua variabel yang digunakan dalam memprediksi kebangkrutan dalam suatu perusahaan. Model Z"-Score awalnya dikembangkan untuk menguji prediksi financial distress untuk perusahaan privat, alasannya karena metode ini adalah versi model Z-Score berbasis akuntansi yang tidak mengandalkan data pasar tetapi data akuntansi (Altman, 1983). Meskipun demikian, kami menggunakan perusahaan publik sebagai sampel. Karena data pasar tidak selalu tersedia, maka kami memutuskan untuk menggunakan model Z"-Score.

Selanjutnya, perhitungan model Altman's Z"-Score yang dimodifikasi dilakukan dengan beberapa langkah. Langkah pertama adalah mengumpulkan data laporan keuangan sampel dalam penelitian ini. Langkah kedua adalah mengklasifikasikan dan menghitung setiap variabel yang dibutuhkan dalam model Altman Z"-Score yang dimodifikasi. Langkah selanjutnya adalah menganalisis prediksi financial distress dengan menjumlahkan hasil dari masing-masing variabel dalam model Altman Z-score yang dimodifikasi. Rumus model Altman Z"-Score dihitung sebagai berikut: $Z=3,25+6,56 X_{1}+3,26 X_{2}+6,72 X_{3}+1,05 X_{4}$

Dimana,

X1: Working capital to total assets (WCTA)

$\mathrm{X} 2$ : Retained earnings to total assets (RE)

$\mathrm{X} 3$ : Earnings before interest and taxes to total assets (EBIT)

$\mathrm{X} 4$ : Book value of equity to book value of total debt (BV)

$\mathrm{Z}$ : Overall index

Klasifikasi perusahaan yang termasuk dalam kategori sehat dan bangkrut pada Z"-Score (Altman, 1983) adalah, (a) $\mathrm{Z}<1,10$ (kategori financial distress); (b) $1,10<\mathrm{Z}<2,60$ (grey area, yaitu rentan terhadap financial distress); (c) $Z>2,60$ (non-financial distress). Selanjutnya hasil perhitungan Altman's Z"-Score memberikan persentase sampel yang termasuk dalam kategori financial distress, grey area, dan tidak terindikasi financial distress. Selain itu, kami melakukan uji kecocokan untuk memastikan bahwa model yang digunakan sesuai untuk diterapkan dalam sampel.

\section{Statistik Deskriptif}

\section{HASIL DAN PEMBAHASAN}

Statistik deskriptif bertujuan untuk memberikan gambaran atau gambaran data melalui rata-rata (mean), maksimum, minimum, standar deviasi, jangkauan dan kemiringan distribusi dalam bentuk kurtosis.

Tabel 4. Statistik Deskriptif 
Owner: Riset \& Jurnal Akuntansi

e-ISSN : 2548-9224|p-ISSN : 2548-7507

Volume 6 Nomor 1, Januari 2022

DOI : https://doi.org/10.33395/owner.v6i1.696

\begin{tabular}{|l|c|c|c|c|}
\hline & WCTA & RE & EBIT & BV \\
\hline Mean & 1.080352 & 1.119558 & 0.717276 & 0.670268 \\
\hline Maksimum & 1.403367 & 1.241369 & 0.900323 & 0.870133 \\
\hline Minimum & 0.757336 & 0.997747 & 0.534230 & 0.470404 \\
\hline Standar Deviasi & 0.326434 & 0.123100 & 0.184984 & 0.470404 \\
\hline Observasi & 48 & 48 & 48 & 48 \\
\hline
\end{tabular}

Berdasarkan tabel 4 terlihat bahwa nilai rata-rata (mean), nilai maksimum, nilai minimum, nilai standar deviasi variabel WCTA, RE, EBIT, dan BV selama dua periode dengan 48 observasi. Nilai rata-rata variabel WTCA adalah 1,080352. Selanjutnya nilai maksimum dari variabel WTCA adalah 1.403367 sedangkan nilai minimumnya adalah 0.757336 . Nilai standar deviasi dari data adalah 0,326434 . Nilai rata-rata yang lebih besar dari nilai standar deviasi menunjukkan keragaman data yang rendah sehingga tingkat deviasi data lebih kecil.

Nilai rata-rata variabel $\mathrm{RE}$ adalah 1,119558. Selanjutnya nilai maksimum variabel RE sebesar 1.241369 dan nilai RE terendah sebesar 0.997747. Sedangkan standar deviasi menunjukkan nilai 0,123100 . Besarnya nilai mean dibandingkan dengan standar deviasi menunjukkan bahwa gap pada data penelitian kecil.

Nilai rata-rata variabel EBIT adalah 0,717276. Selanjutnya nilai maksimum pada data menunjukkan 0,717276 sedangkan nilai minimum adalah 0,534230. Standar deviasi menunjukkan hasil 0,184984 . Nilai mean yang tinggi jika dibandingkan dengan standar deviasi menunjukkan keragaman data yang rendah.

Nilai rata-rata pada variabel BV menunjukkan hasil sebesar 0,670268. Sedangkan nilai maksimum pada data yang diteliti menunjukkan nilai sebesar 0,870133 dan nilai minimum sebesar 0,470404 . Selanjutnya nilai standar deviasi menunjukkan hasil sebesar 0,470404. Hal ini menyiratkan bahwa volatilitas keragaman data rendah, sehingga meminimalkan terjadinya penyimpangan pada data.

\section{Hasil Penelitian}

WCTA adalah rasio yang menunjukkan jumlah modal kerja yang dimiliki perusahaan terhadap total aset yang dimiliki perusahaan. Semakin tinggi rasio WCTA menunjukkan semakin baik kondisi keuangan, sebaliknya semakin rendah WCTA berarti perusahaan mengalami masalah keuangan. Perusahaan harus membuat strategi untuk menetapkan rasio keuangan yang normal untuk menghindari kemungkinan kebangkrutan. Tabel 5 menyajikan hasil perhitungan WCTA pada perusahaan makanan dan minuman selama 2018-2019.

Tabel 5. Working Capital to Total Assets Ratio

\begin{tabular}{|c|r|r|}
\hline Kode Perusahaan & 2018 & \multicolumn{1}{|c|}{2019} \\
\hline ADES & 0,757336 & 1,403367 \\
\hline AISA & 0,97941 & $-2,38208^{*}$ \\
\hline ALTO & $-0,34537^{*}$ & $-0,13823^{*}$ \\
\hline BTEK & $-0,34537^{*}$ & 0,518151 \\
\hline BUDI & $-0,34537^{*}$ & 0,016016 \\
\hline CAMP & 3,941181 & 4,135111 \\
\hline CEKA & 3,652811 & 3,980094 \\
\hline CLEO & $-0,05041^{*}$ & 0,630607 \\
\hline DLTA & 5,132235 & 5,208579 \\
\hline HOKI & 2,658445 & 2,485251 \\
\hline ICPB & 1,314432 & 1,706302 \\
\hline IIKP & $-0,02427^{*}$ & 1,722757 \\
\hline INDF & 0,140561 & 0,458019 \\
\hline MGNA & $-0,13819^{*}$ & $-12,5982^{*}$ \\
\hline MLBI & $-0,79451^{*}$ & $-0,96441^{*}$ \\
\hline MYOR & 2,939724 & 3,11832 \\
\hline PANI & 0,788458 & 1,658646 \\
\hline
\end{tabular}


Owner: Riset \& Jurnal Akuntansi

e-ISSN : 2548-9224 | p-ISSN : 2548-7507

Volume 6 Nomor 1, Januari 2022

DOI : https://doi.org/10.33395/owner.v6i1.696

\begin{tabular}{|r|r|r|}
\hline PCAR & 3,488797 & 2,527706 \\
\hline PSDN & 0,075738 & $-0,79344 *$ \\
\hline ROTI & 2,017036 & 1,075295 \\
\hline SKBM & 0,873634 & 0,795727 \\
\hline SKLT & 0,573986 & 0,705656 \\
\hline STTP & 1,431411 & 1,723151 \\
\hline ULTJ & 2,548447 & 2,859222 \\
\hline
\end{tabular}

*WCTA negatif

Sumber: Data diolah (2021)

Untuk menentukan rasio WCTA diukur dengan membagi modal kerja dengan total aset dan hasilnya dikalikan dengan bobot Z"-Score X1 sebesar 6,56. Berdasarkan tabel 5 dapat dilihat bahwa pada tahun 2018 perusahaan yang memiliki nilai X1 negatif adalah perusahaan masing-masing dengan kode ALTO, BTEK, BUDI sebesar -0,34537, CLEO sebesar -0,5041, IIKP sebesar 0,02427, MGNA sebesar -0,13819 dan MLBI sebesar -0,79451. Sisanya memiliki nilai rasio WCTA yang positif. Sedangkan pada tahun 2019 perusahaan yang memiliki nilai negatif di WCTA adalah AISA sebesar -2.38208, ALTO sebesar -0.13823, MGNA sebesar -12.5982, MLBI sebesar -0.96441 dan PSDN sebesar - 0.79344. Sisanya memiliki nilai WCTA positif.

RE digunakan untuk menghasilkan laba ditahan dengan memanfaatkan seluruh aset yang dimiliki perusahaan. Semakin besar rasio menunjukkan semakin tinggi perusahaan menghasilkan modal berupa tambahan laba ditahan sehingga financial distress akan semakin kecil. Tabel 6 menampilkan perhitungan RE selama tahun 2018 dan 2019.

Tabel 6. Retained Earning To Total Assets Ratio

\begin{tabular}{|c|c|c|}
\hline Kode Perusahaan & 2018 & 2019 \\
\hline ADES & 1,241369 & 0,997747 \\
\hline AISA & 10,26188 & 7,999022 \\
\hline ALTO & 0,416255 & 0,439477 \\
\hline BTEK & $-0,03783^{*}$ & $-0,03371^{*}$ \\
\hline BUDI & 0,330404 & 0,415245 \\
\hline CAMP & 0,313847 & 0,436894 \\
\hline CEKA & 1,989211 & 2,032976 \\
\hline CLEO & 0,52233 & 0,6846 \\
\hline DLTA & 2,664034 & 2,685035 \\
\hline HOKI & 0,431515 & 0,686506 \\
\hline ICPB & 1,421886 & 1,553829 \\
\hline IIKP & $-1,09899^{*}$ & $-0,12686^{*}$ \\
\hline INDF & 0,78324 & 0,90363 \\
\hline MGNA & $-1,2822^{*}$ & $-7,31382^{*}$ \\
\hline MLBI & 1,290989 & 1,263335 \\
\hline MYOR & 1,456175 & 1,570986 \\
\hline PANI & $-0,03436^{*}$ & 0,040244 \\
\hline PCAR & 2,455624 & 2,201431 \\
\hline PSDN & $-0,68006^{*}$ & $-0,82363^{*}$ \\
\hline ROTI & 0,984837 & 1,081516 \\
\hline SKBM & 0,423991 & 0,420233 \\
\hline SKLT & 0,457103 & 0,601727 \\
\hline STTP & 1,862039 & 1,70025 \\
\hline ULTJ & 2,296611 & 2,371659 \\
\hline
\end{tabular}

*RE negatif

Sumber: Data diolah (2021) 
RE menunjukkan peran laba ditahan yang dapat dihasilkan oleh perusahaan dengan menggunakan sumber daya ekonomi yang ada. Untuk melihat besarnya RE dapat dilakukan dengan cara membagi laba ditahan dengan total aset setelah itu hasilnya dikalikan dengan bobot Z"-Score $\mathrm{X} 2$ sebesar 3,26.

Berdasarkan tabel 6 terlihat bahwa pada tahun 2018 perusahaan yang memiliki nilai RE negatif berturut-turut adalah BTEK sebesar -0,03783, IIKP sebesar -1,09899, MGNA sebesar -1,2822, PANI sebesar -0,03436, dan PSDN sebesar -0,68006. Pada tahun 2019, perusahaan yang memiliki nilai RE negatif adalah sebagai berikut, BTEK sebesar -0.03371, IIKP sebesar 0.12686, MGNA sebesar -7.31382, dan PSDN sebesar -0.82363. Sedangkan perusahaan lainnya memiliki nilai RE yang positif.

EBIT adalah rasio yang menunjukkan kemampuan suatu perusahaan untuk menghasilkan laba operasi dari total aset yang dimiliki oleh perusahaan. Laba usaha pada rasio ini adalah laba sebelum pajak dan bunga. Laba sebelum pajak dan bunga adalah laba yang belum digunakan untuk membayar bunga dan beban pajak. Semakin besar EBIT menunjukkan semakin besar kemampuan untuk menghasilkan laba operasi dari aset yang digunakan sehingga mengurangi kemungkinan financial distress. Untuk menentukan rasio EBIT adalah laba sebelum bunga dan pajak dibagi total aset kemudian hasilnya dikalikan dengan bobot Z"-Score X3 sebesar 6,72. Hasil perhitungan EBIT disajikan pada tabel 7 .

Tabel 7. Earnings Before Interest and Taxes to Total Assets

\begin{tabular}{|c|r|r|}
\hline Kode Perusahaan & 2018 & \multicolumn{1}{|c|}{2019} \\
\hline ADES & 0,53423 & 0,900323 \\
\hline AISA & $-0,31659^{*}$ & 4,906031 \\
\hline ALTO & $-0,27656^{*}$ & $-0,06754^{*}$ \\
\hline BTEK & 0,101112 & $-0,1535^{*}$ \\
\hline BUDI & 0,142167 & 0,187962 \\
\hline CAMP & 0,562336 & 0,632492 \\
\hline CEKA & 1,639145 & 0,595237 \\
\hline CLEO & 0,655589 & 0,930128 \\
\hline DLTA & 1,946278 & 1,943625 \\
\hline HOKI & 1,069947 & 1,125805 \\
\hline ICPB & 1,260576 & 1,29107 \\
\hline IIKP & $-0,38045^{*}$ & $-0,2993 *$ \\
\hline INDF & 0,609046 & 0,520212 \\
\hline MGNA & $-1,21447^{*}$ & $-9,21201^{*}$ \\
\hline MLBI & 3,888301 & 3,773221 \\
\hline MYOR & 0,909898 & 0,248662 \\
\hline PANI & $-0,08332^{*}$ & $-0,02856^{*}$ \\
\hline PCAR & $-0,42744^{*}$ & $-0,53277 *$ \\
\hline PSDN & $-0,20961^{*}$ & 0,038541 \\
\hline ROTI & 0,285905 & 0,498176 \\
\hline SKBM & 0,07924 & 0,01906 \\
\hline SKLT & 0,35581 & 0,482492 \\
\hline STTP & 0,829263 & 1,415666 \\
\hline ULTJ & 1,147867 & 1,398581 \\
\hline
\end{tabular}

*EBIT negatif

Sumber: Data Diolah (2021)

Berdasarkan tabel 8 terlihat perusahaan yang memiliki nilai negatif pada rasio EBIT adalah AISA sebesar -0,31659, ALTO sebesar -0,27656, IIKP sebesar -0,38045, MGNA sebesar -1, 21447, PANI sebesar -0,08332, PCAR sebesar - 0,42744, dan PSDN adalah -0,20961 pada tahun 2018 dan ALTO sebesar -0,06754, BTEK sebesar -0,1535, IIKP sebesar -0,2993, MGNA sebesar $-9,21201$, dan PANI sebesar -0,53277 pada tahun 2019, masing-masing. Sedangkan perusahaan lainnya memiliki rasio EBIT positif. 
Rasio BV digunakan untuk mengukur kemampuan perusahaan dalam memenuhi kewajibannya dengan menggunakan ekuitas. BV adalah bagian dari modal dan sumber dukungan untuk kekayaan perusahaan. BV adalah penjumlahan dari hutang jangka pendek dan hutang jangka panjang. Untuk menentukan rasio ini, kami menghitung nilai buku ekuitas dibagi dengan nilai buku hutang. Semakin besar rasio mencerminkan semakin besar kemampuan suatu perusahaan untuk memenuhi kewajibannya dengan memanfaatkan nilai buku modal sehingga semakin kecil financial distress yang dialami perusahaan.

Tabel 8. Book value of equity to book value of total debt ratio

\begin{tabular}{|c|c|c|}
\hline Kode Perusahaan & 2018 & 2019 \\
\hline ADES & 0,870133 & 0,470404 \\
\hline AISA & 1,602668 & 2,233708 \\
\hline ALTO & 1,960218 & 1,993157 \\
\hline BTEK & 1,349217 & 1,388146 \\
\hline BUDI & 1,400565 & 1,85475 \\
\hline CAMP & 0,140945 & 0,137101 \\
\hline CEKA & 0,242973 & 0,206752 \\
\hline CLEO & 0,327908 & 0,656124 \\
\hline DLTA & 0,195708 & 0,18379 \\
\hline HOKI & 0,320251 & 0,386144 \\
\hline ICPB & 0,53917 & 0,473926 \\
\hline IIKP & 0,069369 & 0,095835 \\
\hline INDF & 0,980673 & 0,81354 \\
\hline MGNA & 11,91793 & $-1,93761 *$ \\
\hline MLBI & 1,548615 & 1,604257 \\
\hline MYOR & 1,11227 & 0,969185 \\
\hline PANI & 2,890205 & 2,095159 \\
\hline PCAR & 0,343943 & 0,504898 \\
\hline PSDN & 1,965846 & 3,505871 \\
\hline ROTI & 0,531645 & 0,539663 \\
\hline SKBM & 0,737407 & 0,795303 \\
\hline SKLT & 1,263016 & 1,133037 \\
\hline STTP & 0,628067 & 0,358581 \\
\hline ULTJ & 0,147585 & 0,176998 \\
\hline & &
\end{tabular}

*BV negatif

Sumber: Data diolah (2021)

Rasio BV dapat diukur dengan menghitung nilai buku ekuitas dibagi dengan nilai buku hutang dan hasilnya dikalikan dengan Z"-score 1,05. Berdasarkan tabel 8 terlihat bahwa tidak ada perusahaan yang memiliki nilai BV negatif pada tahun 2018. Sedangkan pada tahun 2019 terdapat perusahaan yang memiliki nilai BV negatif yaitu MGNA sebesar -1,93761.

Selanjutnya langkah terakhir adalah hasil perhitungan model Altman's Z"-Score yang telah dimodifikasi yang diklasifikasikan berdasarkan nilai cut-off, yaitu (a) Perusahaan dalam keadaan financial distress $(Z<1.10)$; (b) Perusahaan dalam kategori grey area, yaitu rentan terhadap financial distress $(1,10<Z<2,60)$; (c) Perusahaan tidak mengalami financial distress $(Z>2,60)$. Tabel 9 menyajikan perhitungan model Altman's Z"-Score pada perusahaan makanan dan minuman di BEI sekitar tahun 2018 dan 2019.

Table 9. Nilai Z"-Score Perusahaan Makanan dan Minuman yang Terdaftar di BEI pada Tahun 2018 dan 2019

\begin{tabular}{|c|c|c|}
\hline Kode Perusahaan & 2018 & 2019 \\
\hline ADES & 6.653068 & 7.021841 \\
\hline AISA & 15.77737 & 16.00668 \\
\hline
\end{tabular}


Owner: Riset \& Jurnal Akuntansi

e-ISSN : 2548-9224 | p-ISSN : 2548-7507

Volume 6 Nomor 1, Januari 2022

DOI : https://doi.org/10.33395/owner.v6i1.696

\begin{tabular}{|c|c|c|}
\hline ALTO & 5.004543 & 5.476864 \\
\hline BTEK & 4.317129 & 4.969087 \\
\hline BUDI & 4.777766 & 5.723973 \\
\hline CAMP & 8.208309 & 8.591598 \\
\hline CEKA & 10.77414 & 10.065059 \\
\hline CLEO & 4.705417 & 6.151459 \\
\hline DLTA & 13.188255 & 13.27103 \\
\hline HOKI & 7.730158 & 7.933706 \\
\hline ICPB & 7.786064 & 8.275127 \\
\hline IIKP & $1.81634 *$ & 4.642432 \\
\hline INDF & 5.76352 & 5.945401 \\
\hline MGNA & 12.53307 & $-27.8116 * *$ \\
\hline MLBI & 9.183395 & 8.926403 \\
\hline MYOR & 9.668067 & 9.157153 \\
\hline PANI & 6.810983 & 7.015489 \\
\hline PCAR & 9.110924 & 7.951265 \\
\hline PSDN & 4.401914 & 5.177342 \\
\hline ROTI & 7.069423 & 6.44465 \\
\hline SKBM & 5.364272 & 5.280323 \\
\hline SKLT & 5.899915 & 6.172912 \\
\hline STTP & 8.00078 & 8.447648 \\
\hline ULTJ & 9.39051 & 10.05646 \\
\hline
\end{tabular}

* gray area; $*$ *financial distress

Sumber: Data diolah (2021)

Berdasarkan tabel 9 terlihat bahwa pada tahun 2018 hanya terdapat satu perusahaan yang masuk dalam grey area yaitu IIKP dengan nilai Z"-Score sebesar 1,81634. Perusahaan yang tersisa tidak mengalami financial distress ataupun berada dalam grey area. Pada tahun 2019 diketahui ada satu perusahaan yang mengalami financial distress $(Z<1.10)$ yaitu MGNA dengan nilai Z"-Score sebesar -27.8116. Sementara perusahaan lainnya dalam kondisi keuangan yang aman.

Table 10. Persentase Hasil Perhitungan Altman 's Z'-Score

\begin{tabular}{|l|c|r|}
\hline & $\mathrm{N}=24$ & Marginal Percentage \\
\hline Financial Distress & 1 & $2.1 \%$ \\
\hline Grey Area & 1 & $2.1 \%$ \\
\hline Non Financial Distress & 46 & $95.8 \%$ \\
\hline Valid & 48 & $100.0 \%$ \\
\hline Missing & 0 & \\
\hline Total & 48 & \\
\hline
\end{tabular}

Sumber: Data diolah (2021)

Hasil persentase menunjukkan bahwa sebanyak perusahaan mengalami financial distress dengan persentase marginal sebesar 2,1 persen. Satu perusahaan yang termasuk dalam financial distress adalah MGNA pada tahun 2019. Selanjutnya, ada satu perusahaan yang mengalami kondisi rentan (grey area) dengan persentase marjinal 2,1 persen. Perusahaan yang termasuk dalam kategori rentan adalah IIKP pada tahun 2018. Sisanya perusahaan yang terdaftar, yaitu 95,8 persen termasuk dalam non financial distress.

\section{Robustness Check}

Sebelum melakukan uji goodness of fit, kami melakukan model fit dan Pseudo R-square untuk memastikan bahwa hasilnya kuat dan dapat diandalkan untuk data kami. Hasil pengujian disajikan pada tabel A1 dan A2 pada bagian lampiran. Goodness of fit merupakan teknik analisis data dalam menunjukkan uji kesesuaian model dengan data. Hasil Goodness of fit test ditampilkan sebagai berikut: 
Tabel 11. Hasil Tes Goodness of Fit

\begin{tabular}{|l|r|r|r|}
\hline \multicolumn{4}{|c|}{ Goodness-of-Fit } \\
\hline & Chi-Square & \multicolumn{1}{c|}{ Df } & \multicolumn{1}{c|}{ Sig. } \\
\hline Pearson &, 000 & 47 & 1,000 \\
\hline Deviance &, 000 & 47 & 1,000 \\
\hline
\end{tabular}

Sumber: Data diolah (2021)

Berdasarkan tabel 11 dijelaskan bahwa Chi-Square adalah 0,000 untuk koefisien Pearson dengan signifikansi 1.000 dan Chi-Square adalah 0,000 untuk koefisien deviance. Karena nilai signifikansi Pearson adalah 1.000 atau lebih besar dari alpha 0,05, hal ini menunjukkan bahwa model logit cocok dengan data penelitian ini.

\section{KESIMPULAN}

Nilai rata-rata WCTA, RE, EBIT dan BV masing-masing adalah 1,080352, 1,119558, 0,717276, dan 0,670268. Statistik deskriptif menunjukkan bahwa tidak ada kesenjangan dalam data yang diamati. Hal ini disebabkan karena variasi data yang kecil atau nilai mean yang tinggi dibandingkan dengan standar deviasi. Selanjutnya, hasil perhitungan Altman's Z"-Score yang dimodifikasi dalam memprediksi financial distress pada perusahaan makanan dan minuman yang terdaftar di BEI pada tahun 2018 menunjukkan bahwa tidak ada satupun perusahaan yang termasuk dalam kategori financial distress, satu perusahaan termasuk dalam grey area dan 23 perusahaan tidak mengalami kesulitan keuangan. Pada tahun 2019, hanya ada satu perusahaan yang mengalami financial distress, tidak ada satupun perusahaan yang masuk dalam grey area, dan 23 perusahaan tidak mengalami financial distress. Selain itu, hasil Altman's Z"'-Score secara keseluruhan dalam persentase menunjukkan bahwa kategori perusahaan yang mengalami financial distress $(Z<1.10)$, grey area, dan non-financial distress masing-masing adalah 2.1, 2.1, dan 95,8 persen.

Hasil penelitian menunjukkan bahwa pada periode 2018 dan 2019 perusahaan yang tidak mengalami financial distress adalah hampir seluruh sampel yaitu 95,8 persen. Besarnya persentase perusahaan yang tidak mengalami financial distress menunjukkan bahwa industri tersebut relatif aman, jika tidak ada guncangan ekonomi di masa depan. Namun, sinyal diberikan untuk perusahaan yang termasuk dalam kesulitan keuangan dan grey are. Seperti teori yang dikembangkan oleh Altman dan mendukung teori sinyal, bahwa sinyal kesulitan keuangan memberikan informasi yang buruk kepada pihak yang berkepentingan. Prediksi tersebut menunjukkan bahwa perusahaan dalam kategori tersebut harus lebih menyadari kondisi keuangan mereka yang buruk. Selain itu, perusahaan dalam kesulitan keuangan dan grey area lebih sensitif terhadap guncangan ekonomi sehingga diperlukan mitigasi untuk mencegah kebangkrutan.

Di sisi lain, teori keagenan bertentangan dengan hasil ini yang menyatakan bahwa kesulitan keuangan menunjukkan manajemen yang buruk daripada financial distress (Jensen dan Meckling, 1976). Dengan peringatan dini berupa prediksi financial distress, perusahaan yang berhasil melakukan pengelolaan ulang justru menunjukkan kinerja yang baik pada periode berikutnya, tidak mengarah pada kebangkrutan (Whitaker, 1999). Oleh karena itu, perusahaan yang terindikasi financial distress atau grey area perlu mengkaji apakah kategori financial distress yang dialaminya disebabkan oleh kesulitan ekonomi atau bahkan karena manajemen yang buruk.

Selain itu, penelitian ini memberikan kontribusi kepada pemegang saham dan pemangku kepentingan (pelanggan, pemasok, dan karyawan), terkait dengan prediksi kesulitan keuangan, khususnya di sektor makanan dan minuman. Perusahaan yang berada dalam financial distress dan grey area dapat dijadikan sebagai peringatan dini dalam menentukan portofolio investasi bagi investor dan calon investor. Bagi pihak manajemen, hasil tersebut dapat menjadi sinyal dalam menilai kondisi keuangan suatu perusahaan sehingga dapat menjadi bahan pertimbangan dalam pengambilan keputusan terkait kebijakan keuangan. Selain itu, hasil penelitian ini memberikan informasi tentang kemungkinan kondisi financial distress pada industri makanan dan minuman di Indonesia. 


\section{REFERENCES}

Agarwal, V. and R. Taffler. (2008). Comparing the Performance of Market-Based and AccountingBased Bankruptcy Prediction Models. Journal of Banking and Finance 32, 1541-1551.

Altman, E.I. (1968). Financial Ratios, Discriminant Analysis and the Prediction of Corporate Bankruptcy. Journal of Finance 23, 589-609.

Altman, E.I. (1983). Corporate Financial Distress: A Complete Guide to Predicting, Avoiding, and Dealing with Bankruptcy. Hoboken: Wiley Interscience, John Wiley and Sons.

Altman, E. I., Iwanicz-Drozdowska, M., Laitinen, E. K., \& Suvas, A. (2016). Financial Distress Prediction in an International Context: A Review and Empirical Analysis of Altman's ZScore Model. Journal of International Financial Management \& Accounting, 28(2), 131171. doi:10.1111/jifm.12053.

Bauer, J. \& V. Agarwal, V. (2014). Are Hazard Models Superior to Traditional Bankruptcy Prediction Approaches? A Comprehensive Test. Journal of Banking and Finance 40, 432442.

Das, S. R., Hanouna, P., \& Sarin, A. (2009). Accounting-Based Versus Market-Based CrossSectional Models of CDS Spreads. Journal of Banking and Finance 33, 719-730.

Hamid, T., Akter, F., \& Rab, N. B. (2016). Prediction of Financial Distress of Non-Bank Financial Institutions of Bangladesh using Altman's Z Score Model. International Journal of Business and Management 11(12). Doi: http://dx.doi.org/10.5539/ijbm.v11n12p261.

Intan, K., Patunrui, A., \& Yati, S. (2017). Analisis Penilaian Financial Distress Menggunakan Model Altman (Z-Score) Pada Perusahaan Farmasi Yang Terdaftar di Bursa Efek Indonesia Periode 2013-2015. Jurnal Akuntansi, Ekonomi dan Manajemen Bisnis 5(1), 55-71.

Jensen, M. C., \& Meckling, W. H. (1976). Theory of the Firm: Managerial Behavior, Agency Costs and Ownership Structure. Journal of Financial Economics 3, 305-360.

Kementrian Perindustrian. (2017). Retrieved from https://kemenperin.go.id/artikel/18465/IndustriMakanan-dan-Minuman-Masih-Jadi-Andalan.

Kementrian Perindustrian. (2021). Retrieved from https://kemenperin.go.id/artikel/22485/IndustriMakanan-dan-Minuman-Diakselerasi-Menuju-Transformasi-Digital.

Morris, R. D. (1987). Signalling, Agency Theory and Accounting Policy Choice. Accounting and Business Research, 18(69), 47-56, Doi: 10.1080/00014788.1987.9729347

Nurhayati, D., Dewi, R. R., \& Fajri, R. N. (2021). Pengaruh Rasio Keuangan Terhadap Financial Distress pada Industri Food and Beverage di Bursa Efek Indonesia Periode 2017-2019. Ekonomis: Journal of Economics and Business 5(1), 59-64.

Opler, T. C., \& Titman, S. (1994). Financial Distress and Corporate Performance. The Journal of Finance, 49(3), 1015-1040. Doi:10.1111/j.1540-6261.1994.tb00086.x

Panigrahi, A. (2019). Validity of Altman's "Z" Score Model in Predicting Financial Distress of Pharmaceutical Companies. NMIMS JOURNAL OF ECONOMICS AND PUBLIC POLICY 4(1).

Whitaker, R.B. (1999). The early stages of financial distress. J Econ Finan 23, 123-132. Doi: https://doi.org/10.1007/BF02745946. 